\title{
Impacts of light use efficiency and fPAR parameterization on gross primary production modeling
}

\author{
Yen-Ben Cheng ${ }^{\mathrm{a}, *}$, Qingyuan Zhang ${ }^{\mathrm{b}}$, Alexei I. Lyapustin ${ }^{\mathrm{c}}$, Yujie Wang ${ }^{\mathrm{d}}$, \\ Elizabeth M. Middleton ${ }^{\mathrm{e}}$ \\ a Earth Resources Technology, Inc., Laurel, MD 20707, USA \\ b Unversities Space Research Association, Columbia, MD 21044, USA \\ c Climate and Radiation Laboratory, National Aeronautics and Space Administration Goddard Space Flight Center, Greenbelt, MD 20771, USA \\ d University of Maryland Baltimore County, Baltimore, MD 21228, USA \\ e Biospheric Sciences Laboratory, National Aeronautics and Space Administration/Goddard Space Flight Center, Greenbelt, MD 20771, USA
}

\section{A R T I C L E I N F O}

\section{Article history:}

Received 7 August 2013

Received in revised form

12 November 2013

Accepted 6 January 2014

\section{Keywords:}

Carbon modeling

Fraction of photosynthetically active

radiation

fAPAR $_{\text {chl }}$

Light use efficiency

\begin{abstract}
A B S T R A C T
This study examines the impact of parameterization of two variables, light use efficiency (LUE) and the fraction of absorbed photosynthetically active radiation (fPAR or fAPAR), on gross primary production (GPP) modeling. Carbon sequestration by terrestrial plants is a key factor to a comprehensive understanding of the carbon budget at global scale. In this context, accurate measurements and estimates of GPP will allow us to achieve improved carbon monitoring and to quantitatively assess impacts from climate changes and human activities. Spaceborne remote sensing observations can provide a variety of land surface parameterizations for modeling photosynthetic activities at various spatial and temporal scales. This study utilizes a simple GPP model based on LUE concept and different land surface parameterizations to evaluate the model and monitor GPP. Two maize-soybean rotation fields in Nebraska, USA and the Bartlett Experimental Forest in New Hampshire, USA were selected for study. Tower-based eddy-covariance carbon exchange and PAR measurements were collected from the FLUXNET Synthesis Dataset. For the model parameterization, we utilized different values of LUE and the fPAR derived from various algorithms. We adapted the approach and parameters from the MODIS MOD17 Biome Properties Look-Up Table (BPLUT) to derive LUE. We also used a site-specific analytic approach with tower-based Net Ecosystem Exchange (NEE) and PAR to estimate maximum potential LUE (LUE max $_{\text {) }}$ to derive LUE. For the fPAR parameter, the MODIS MOD15A2 fPAR product was used. We also utilized APAR $_{\text {chl }}$, a parameter accounting for the fAPAR linked to the chlorophyll-containing canopy fraction. fAPAR $\mathrm{R}_{\text {chl }}$ was obtained by inversion of a radiative transfer model, which used the MODIS-based reflectances in bands 1-7 produced by Multi-Angle Implementation of Atmospheric Correction (MAIAC) algorithm. fAPAR chl $_{\text {exhibited sea- }}$ sonal dynamics more similar with the flux tower based GPP than MOD15A2 fPAR, especially in the spring and fall at the agricultural sites. When using the MODIS MOD17-based parameters to estimate LUE, fAPAR $_{\text {chl }}$ generated better agreements with GPP $\left(r^{2}=0.79-0.91\right)$ than MOD15A2 fPAR $\left(r^{2}=0.57-0.84\right)$. However, underestimations of GPP were also observed, especially for the crop fields. When applying the site-specific LUE ${ }_{\max }$ value to estimate in situ LUE, the magnitude of estimated GPP was closer to in situ GPP; this method produced a slight overestimation for the MOD15A2 fPAR at the Bartlett forest. This study highlights the importance of accurate land surface parameterizations to achieve reliable carbon monitoring capabilities from remote sensing information.
\end{abstract}

(C) 2014 Elsevier B.V. All rights reserved.

\section{Introduction}

Carbon sequestration by terrestrial plants is a key factor to a comprehensive understanding of carbon budget at the global

\footnotetext{
* Corresponding author at: Code 618, NASA Goddard Space Flight Center, Greenbelt, MD 20771, USA, Tel.: +1 301614 6636; fax: +1 3016146695.

E-mail address: Yen-Ben.Cheng@nasa.gov (Y.-B. Cheng).
}

scale. Carbon assimilation through photosynthesis by vegetation, known as gross primary production (GPP) at the ecosystem scale, is the largest carbon exchange between the biosphere and the atmosphere (Beer et al., 2010). Accurate measurements and estimates of GPP will allow us to achieve improved carbon monitoring and to quantitatively assess impacts from climate changes and human activities (Grace et al., 2007; Middleton et al., 2011). Remote sensing observations can provide a variety of land surface parameterizations for modeling photosynthetic activities at various spatial 
and temporal scales, and much effort has been put towards this goal over the past decades. Many remote-sensing-based indices and algorithms tracking leaf biochemical properties (e.g., chlorophyll, water content) and canopy biophysical properties (e.g., leaf area index, LAI; fraction of photosynthetically active radiation (PAR) absorbed by vegetation canopy (fPAR or fAPAR) have been developed to estimate GPP with different approaches for various ecosystems with variable success (Cheng et al., 2007; Grace et al., 2007; Heinsch et al., 2006; Houborg et al., 2011; Peng and Gitelson, 2012; Running et al., 2004; Sellers et al., 1997; Tucker and Sellers, 1986; Turner et al., 2006; Wu et al., 2011, 2009; Xiao et al., 2010, 2004a; Zhang et al., 2009).

The concept of the light use efficiency (LUE) model (Monteith, 1972,1977 ) has been widely used for GPP modeling. The approach describes carbon sequestration as a product of the capability and efficiency of vegetation to capture and convert solar radiation into biomass by terrestrial vegetation. The model is usually defined as:

$\mathrm{GPP}=\varepsilon \times \mathrm{PAR} \times f \mathrm{PAR}$

where $\varepsilon$ is LUE over a defined period of time. Many previous studies have utilized the model and coupled it with remote sensing data to estimate GPP at various spatial scales (Cheng et al., 2009; Drolet et al., 2008; Hall et al., 2012; Hilker et al., 2012; Huntzinger et al., 2012; Middleton et al., 2009; Nichol et al., 2000; Schaefer et al., 2012), including the Moderate Resolution Imaging Spectroradiometer(MODIS) Terra/Aqua satellite GPP Products (Heinsch et al., 2006; Running et al., 2004; Turner et al., 2006; Zhao et al., 2005). The algorithm used to deliver the MODIS MOD17A2 GPP product utilizes a biome-based look-up table (LUT) to determine the potential maximum LUE ( $\mathrm{LUE}_{\max }$ or $\varepsilon_{\max }$ ), and assumes down-regulation based on ambient air temperature and vapor pressure deficit (VPD).

The MODIS MOD17 product utilizes the MODIS MOD15A2 fPAR product in the procedure. The MODIS MOD15A2 algorithm incorporates atmospherically corrected MODIS surface reflectance and a LUT method to achieve inversion of the three dimensional radiative transfer process in vegetation canopies. A back-up method based on relationships between the normalized difference vegetation index (NDVI) and LAI and FPAR is used when the inversion method fails to deliver (Knyazikhin et al., 1999, 1998; Myneni et al., 2002). This approach estimates the fAPAR associated with the entire canopy or ecosystem, comprised of both photosynthetic and non-photosynthetic components. The concept of retrieving fAPAR for the chlorophyll-containing canopy actively involved in photosynthesis was proposed by Zhang and colleagues (Zhang et al., $2013,2012,2009,2005)$. This retrieval was designed to account for only the solar energy absorbed by chlorophyll of the foliage and contributing to photosynthesis. This was accomplished by inversion of a linked leaf-canopy radiative transfer model using surface reflectance of five or seven MODIS land bands (Zhang et al., 2013, 2012, 2009, 2005).

The vegetation photosynthesis model (VPM) is another simple GPP model based on remote sensing observations and micrometeorological data (Kalfas et al., 2011; Wang et al., 2010; Xiao et al., 2004a,b; Xiao et al., 2005). The VPM model adapted the LUE concept and calculates GPP as the product of PAR, fAPAR of the photosynthetically active vegetation (denoted as fAPAR pav $_{\text {or }}$ APAR $_{\text {chl }}$ ), and LUE $(\varepsilon)$. The Enhanced Vegetation Index, EVI (Huete et al., 2002),

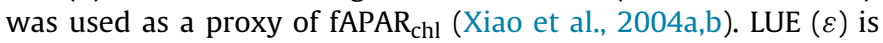
derived as the potential maximum LUE $\left(\varepsilon_{\max }\right)$ down-regulated by scalars of temperature, water, and phenology. The $\varepsilon_{\max }$ value is usually determined either from previous studies or from an analytical approach based on flux tower net ecosystem exchange (NEE) and PAR. This model has been used and examined with various vegetation types including deciduous and evergreen forests, crop (maize), grassland, and savannah woodlands (Jin et al., 2013; Kalfas et al., 2011; Wang et al., 2010; Xiao et al., 2004a,b, 2005).
The importance of accurate estimate of both fPAR and LUE for improved carbon monitoring capabilities has been pointed out in recent studies. For instance Bonan and colleagues (Bonan et al., 2011) suggested the accurate radiative transfer parameterization within the canopy (e.g., fPAR) is necessary to improve output accuracy of the simulated GPP from Community Land Model version 4 (CLM4). LUE has been shown to have significant variations across vegetation types (Anderson et al., 2000; Gower et al., 1999). When applied to models, large errors were found and stem from biases in LUE that accumulate in the calculation of annual carbon assimilation (Lin et al., 2011). Therefore, in this paper, we integrated the LUE concept with different approaches for determining the parameters $\varepsilon$ and fPAR to estimate carbon assimilation (GPP) at three FLUXNET sites, two agricultural sites and one deciduous forest site. Our objectives are to validate the capability to model and monitor GPP using the simple LUE concept and to compare results from different parameterization schemes.

\section{Methods}

\subsection{Study sites}

In this study, we investigated the capability of a simple model based on the LUE concept to estimate GPP at three FLUXNET sites using different land surface parameterizations. The first two sites are maize-soybean rotation crop fields located near Mead, Nebraska, USA. The third site is the Bartlett Experimental Forest in New Hampshire, USA. These sites were selected based on their phenological characteristics and the availability of flux data, micrometeorological measurements, and remote sensing observations. Furthermore, they provided us the opportunity to examine the model on different vegetation types in both native and managed ecosystems.

\subsubsection{Maize-soybean rotation crop fields, Nebraska (US-NE2 and US-NE3)}

Two of the three crop fields located at the University of Nebraska Agricultural Research and Development Center near Mead, NE, USA were selected to study. Both fields have maize (Zea mays L.)- soybean (Glycine max [L.] Merr.) rotations, but depend differently on water supply. The 52.4 ha US-NE2 site $\left(41.1649^{\circ} \mathrm{N}, 96.4701^{\circ} \mathrm{W}\right)$ is equipped with a center pivot irrigation system while the 65.4 ha US-NE3 site $\left(41.1797^{\circ} \mathrm{N}, 96.4396^{\circ} \mathrm{W}\right)$ relies on rainfall (Verma et al., 2005). The soils are deep silty clay loams. The fields were uniformly tilled by disking prior to 2001 and since then have been managed as a no-till system. Both fields are equipped with eddy covariance tower systems to measure energy and $\mathrm{CO}_{2}$ fluxes (Verma et al., 2005). In this study, the data from 2001 through 2004 were collected at the two sites and analyzed.

\subsubsection{Bartlett experimental forest, New Hampshire (US-BAR)}

The Bartlett Experimental Forest $\left(44.0646^{\circ} \mathrm{N}, 71.2881^{\circ} \mathrm{W}\right)$ is located within the White Mountains National Forest in northern central New Hampshire, USA (Jenkins et al., 2007). The 1050 ha forest is managed by the USDA Forest Service Northeastern Research Station. The forest experiences a humid continental climate with short cool summers and long cold winters (Jenkins et al., 2007). A $26.5 \mathrm{~m}$ high tower was installed for continuous eddy covariance fluxes and meteorological measurements in a low-elevation northern hardwood stand, where the average canopy height was approximately $20-22 \mathrm{~m}$. In the tower footprint, the forest is predominantly classified into red maple (Acer rubrum), sugar maple (Acer saccharum), and American beech (Fagus grandifolia), for which LAI in the vicinity was reported to be 3.6 to 4.5 (Jenkins et al., 
2007). Available data from 2004 through 2005 were collected for this study.

\subsection{Flux data collection}

Flux and meteorological variables were collected from the FLUXNET Synthesis Dataset (http://www.fluxdata.org) for the study sites. The Synthesis Dataset provides a collaboration portal for flux and meteorological data collected worldwide (Agarwal et al., 2010). The data are quality-checked and gap-filled based on guidelines and previous studies (Agarwal et al., 2010; Falge et al., 2001; Munger and Loescher, 2006). NEE was processed following the FLUXNET procedure, from which GPP values were computed (Agarwal et al., 2010). For the maize-soybean rotation crop fields (US-NE2, US-NE3), daily observations, including air temperature, vapor pressure deficit (VPD), GPP, and PAR, were collected from 2001 through 2004. For the Bartlett forest (US-BAR), daily measurements from 2004 and 2005 were obtained.

\subsection{MODIS data processing}

The MODIS data were processed using the Multi-angle implementation of atmospheric correction (MAIAC) algorithm (Lyapustin et al., 2011a,b, 2012). MAIAC is an advanced algorithm which uses time series analysis and a combination of pixel-based and image-based processing to improve the accuracy of cloud/snow detection, aerosol retrievals, and atmospheric correction based on the BRDF model of surface. For this work, we used MODIS Collection 6 calibrated and geolocated (level 1B) data. The derived surface reflectance in MODIS bands 1 (620-670 nm), 2 (841-876 nm), 3 (459-479 nm), 4 (545-565 nm), $5(1230-1250 \mathrm{~nm}), 6(1628-1652 \mathrm{~nm})$, and $7(2105-2155 \mathrm{~nm})$ were then utilized to calculate $\mathrm{fAPAR}_{\mathrm{chl}}$, as shown below, for the study sites.

\subsection{Model parameterization}

For the GPP model [1] utilized in this study, the PAR values were obtained from the FLUXNET dataset. Different approaches were used to determine the remaining two parameters, $\varepsilon$ and fPAR.

\subsubsection{Light use efficiency}

The MODIS MOD17 GPP products (Running et al., 2004) come from an algorithm that describes the parameter $\varepsilon$ as the downregulated value of the maximum radiation conversion efficiency $\left(\varepsilon_{\max }\right)$. The down-regulation is driven by sub-optimal environmental conditions determined by air temperature and VPD:

$\varepsilon=\varepsilon_{\max } \times T \min _{\text {scalar }} \times \mathrm{VPD}_{\text {scalar }}$

where $T \min _{\text {scalar }}$ and $\mathrm{VPD}_{\text {scalar }}$ are dimensionless multipliers describing relative decreases of $\varepsilon_{\max }$ and photosynthesis due to cold temperature and high VPD. These scalars are defined as simple linear ramp functions using prescribed minimum and maximum environmental constraints $\left(T \min _{\min }\right.$ and $T \min _{\max }, V_{P D} \min$ and $V_{P D}$ max $)$ based on broad global biome classes. Detailed descriptions can be found in previous publications (Heinsch et al., 2003, 2006). We adapted the Biome Properties Look-Up Table (BPLUT) used to derive the MOD17 product. The values of $\varepsilon_{\max }$ and parameters needed to calculate $T \mathrm{~min}_{\text {scalar }}$ and $\mathrm{VPD}_{\text {scalar }}$ are listed in Table 1.

In addition to the BPLUT values used in the MODIS MOD17 product (Table 1), we also utilized a site-specific analysis between NEE and PAR to determine $\varepsilon_{\max }$. The analysis is usually done by performing a linear or nonlinear fitting to half-hourly or hourly data collected at flux tower sites (Ruimy et al., 1995; Wofsy et al., 1993). The approach has been adapted in many previous studies to determine the $\varepsilon_{\max }$ value for different sites (Wang et al., 2010; Xiao,
Table 1

Biome properties look-up table (BPLUT) describing parameters used in GPP model.

\begin{tabular}{lll}
\hline Site & US-NE2 and US-NE3 & US-BAR \\
\hline Vegetation type & Crop & Deciduous broadleaf forest \\
$\varepsilon_{\max }(\operatorname{kg} C \mathrm{MJ}-1)$ & 0.000680 & 0.001044 \\
$\mathrm{Tmin}_{\min }\left({ }^{\circ} \mathrm{C}\right)$ & -8.00 & -8.00 \\
$\mathrm{Tmin}_{\max }\left({ }^{\circ} \mathrm{C}\right)$ & 12.02 & 7.94 \\
$\mathrm{VPD}_{\min }(\mathrm{Pa})$ & 650 & 650 \\
$\mathrm{VPD}_{\max }(\mathrm{Pa})$ & 4100 & 2500 \\
\hline
\end{tabular}

2006; Xiao et al., 2004a, 2005). Following the description and examples established in previous studies (Wang et al., 2010; Xiao et al., 2004a, 2005), we utilized the hourly PAR and flux data collected from the FLUXNET Synthesis Dataset and applied a nonlinear hyperbolic model to estimate $\varepsilon_{\max }$ for each of the study sites. The derived $\varepsilon_{\text {max }}$ values were then used as input in Eq. (2) to calculate $\varepsilon$, in addition to the values computed based on $\varepsilon_{\text {max }}$ adapted from MODIS MOD17 algorithm (Table 1).

\subsubsection{Fraction of absorbed PAR}

We utilized two different values for the fPAR parameter. One is from the MOD15A2 LAI/fPAR product. The MOD15A2 LAI/fPAR product was downloaded from Oak Ridge National Laboratory (ORNL) Distributed Active Archive Center (DAAC) for Biogeochemical Dynamics (http://daac.ornl.gov/MODIS/). The MODIS MOD15A2 fPAR product represents the fraction of PAR absorbed by the whole canopy.

The concept of fAPAR associated with the foliage chlorophyll content ( fAPAR $_{\text {chl }}$ ) accounts for the PAR absorbed by chlorophyll throughout a canopy $\left(\mathrm{APAR}_{\mathrm{chl}}\right)$ used in the photosynthesis process, as compared to the PAR absorbed by the whole canopy (e.g., MOD15A2 fPAR). The fAPAR $_{\text {chl }}$ concept partitions a vegetation canopy into leaf and non-leaf (referred to as stem) components. The leaf can be further partitioned into chlorophyll, non-photosynthetic pigments (referred to as brown pigment) and dry matter fractions. The PROSPECT (Baret and Fourty, 1997; Jacquemoud and Baret, 1990) leaf radiative transfer model (RTM) and the SAIL2 (Braswell et al., 1996) canopy RTM were coupled to account for the different foliage fractions and full canopies. The fAPAR values for the

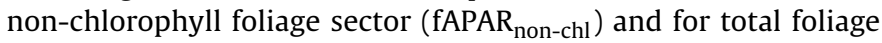
( $\left.\mathrm{fAPAR}_{\text {foliage }}\right)$ can be computed as:

$f \mathrm{APAR}_{\text {non-chl }}=f \mathrm{APAR}_{\text {brown_pigment }}+f \mathrm{APAR}_{\mathrm{dry} \_ \text {matter }}$
$f \mathrm{APAR}_{\text {foliage }}=f \mathrm{APAR}_{\mathrm{chl}}+f \mathrm{APAR}_{\text {non-chl }}$

Each MODIS surface reflectance observation $\left(\rho_{\mathrm{obs}}\right)$ contained some noise, and was associated with a specific geometries for view zenith angle $\left(\theta_{\mathrm{v}}\right)$, relative view azimuth angle $(\phi)$, and solar zenith angle $\left(\theta_{\mathrm{s}}\right)$, all expressed in degrees. Therefore, we treated each reflectance observation as a sample of the following distribution:

$\rho \sim\left\{\rho_{\text {obs }}\left(\lambda, \theta_{v}(1+3 N(0,1)), \theta_{s}(1+3 N(0,1)), \phi(1+3 N(0,1))\right)\right\}$

$\cdot(1+0.05 N(0,1))$

where $\mathrm{N}(0,1)$ was the normal distribution with a mean of zero and $\mathrm{SD}=1$. We used multiple samples from this distribution in Eq. (5). The Markov Chain Monte Carlo (MCMC) procedure was implemented for the inversion of the models to calculate the parameter $\mathrm{fAPAR}_{\mathrm{chl}}$. A detailed description of the algorithm can be found in previous publications (Zhang et al., 2005, 2009, 2012, 2013). In

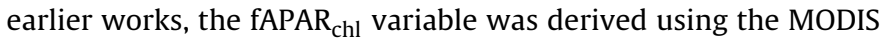
MOD09 surface reflectance product and the Earth Observing-1 (EO1) Hyperion imagery and was shown to be a useful parameter that improved carbon monitoring (Zhang and Middleton, 2010; Zhang et al., 2005, 2006, 2009, 2012, 2013). In this study, MAIAC-processed 
MODIS reflectance band 1-7 was used to calculate fAPAR $_{\mathrm{chl}}$ for the

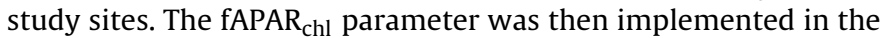
LUE model to estimate GPP.

In summary, we utilized two different values of $\varepsilon_{\max }$ values with the MODIS MOD17 algorithm, Eq. (2), to calculate $\varepsilon$. We linked the $\varepsilon$ values to two different fPAR values, MODIS MOD15A2 fPAR and fAPAR $\mathrm{chl}_{\mathrm{c}}$, to estimate GPP at eight-day temporal scale for all of the study sites. Four combinations of the different land surface parameterizations were examined and are summarized in Table 2.
Table 2

Combinations of LUE $(\varepsilon)$ and fPAR parameterization examined in this study. Note, $\varepsilon_{\max }$ values were used in the MODIS MOD17 like algorithm (Eq. (2)) to determine $\varepsilon$ for the GPP model.

\begin{tabular}{lll}
\hline & $\varepsilon_{\max }$ & fPAR \\
\hline Case I & MODIS MOD17 BPLUT & MOD15A2 fPAR \\
Case II & MODIS MOD17 BPLUT & fAPAR $_{\text {chl }}$ \\
Case III & Analytic approach, site specific & MOD15A2 fPAR $_{\text {Case IV }}$ \\
\hline
\end{tabular}
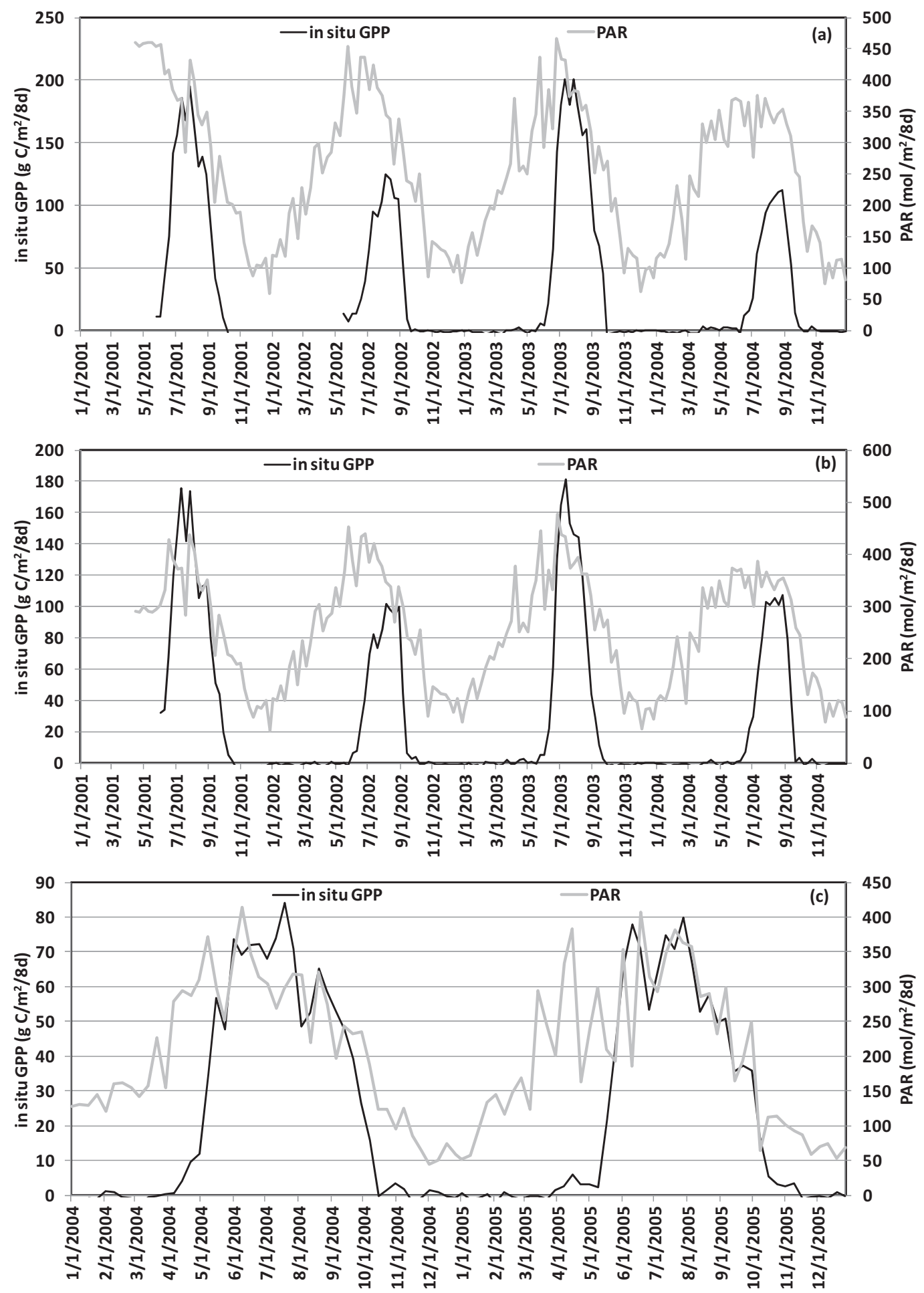

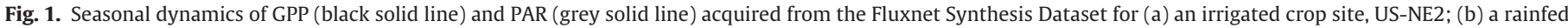
crop site, US-NE3 in 2001 through 2004 and (c) a deciduous forest, US-BAR in 2004 and 2005. 

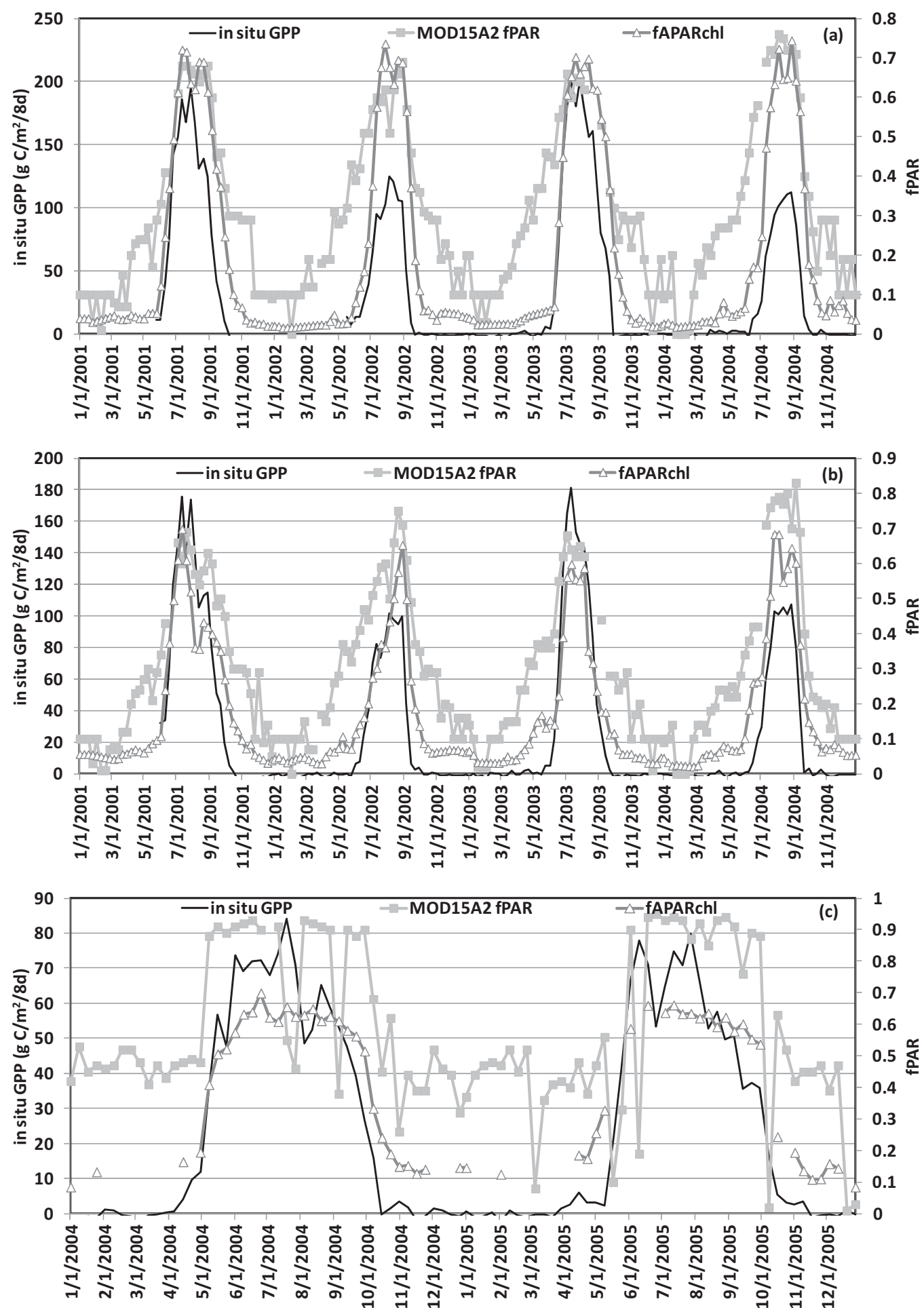

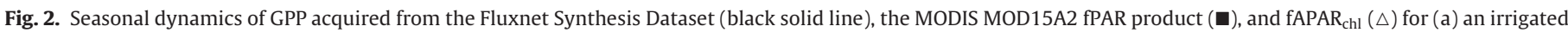
crop site, US-NE2; (b) a rainfed crop site, US-NE3 in 2001 through 2004 and (c) a deciduous forest, US-BAR in 2004 and 2005.

\section{Results}

Values of GPP(black solid line) and PAR (grey solid line) acquired from the FLUXNET Synthesis Dataset are shown in the format of eight-day values for the three study sites, rotation maize-soybean field (US-NE2, US-NE3) and the Bartlett Experimental Forest (USBAR), in Fig. 1a, b, c, respectively. Notable differences were observed for the two alternating crop types in US-NE2 and US-NE3 (Fig. 1a, b). Maize showed much higher productivity in 2001 and 2003 than soybean in 2002 and 2004. GPP in all three sites exhibited pronounced seasonal patterns (Fig. 1 ) with very low productivities in winter, that increased in springtime after planting (for agricultural sites) or green-up (for forest site), and with peak GPP observed in summer, decreasing in fall. Seasonal dynamics of the MODIS MOD15A2 fPAR product $(\boldsymbol{\square})$ and fAPAR chl $\left._{(} \triangle\right)$ are shown as eight-day average values in Fig. 2 for the three study sites. All three variables (GPP, MOD15A2 fPAR, and APAR $_{\text {chl }}$ ) showed clear differences between growing and non-growing seasons. For 

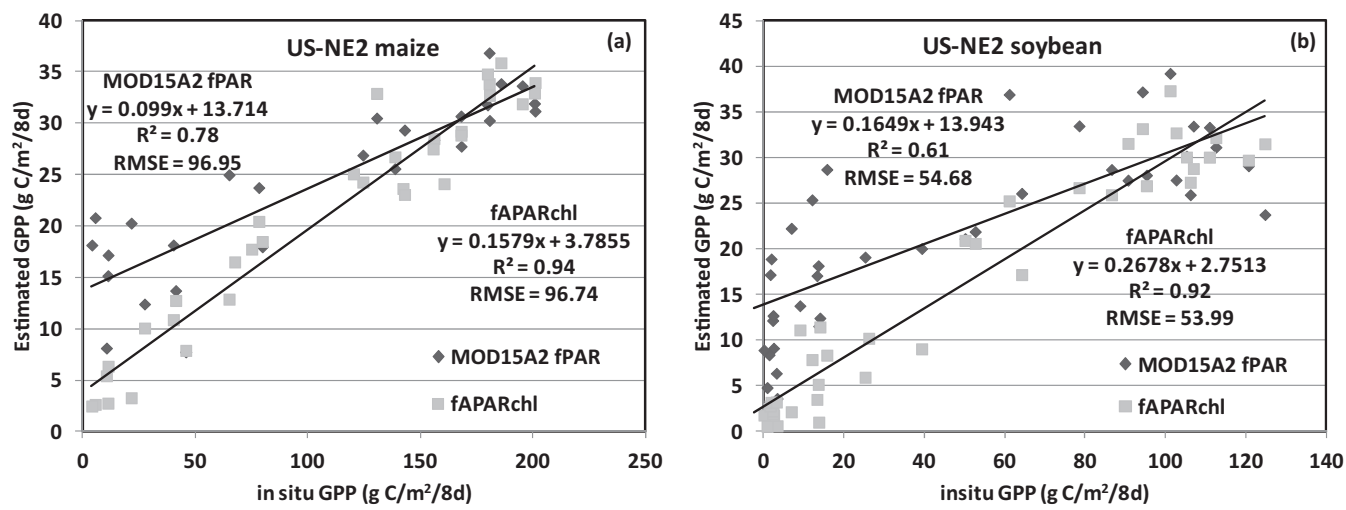

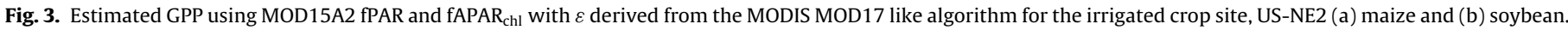
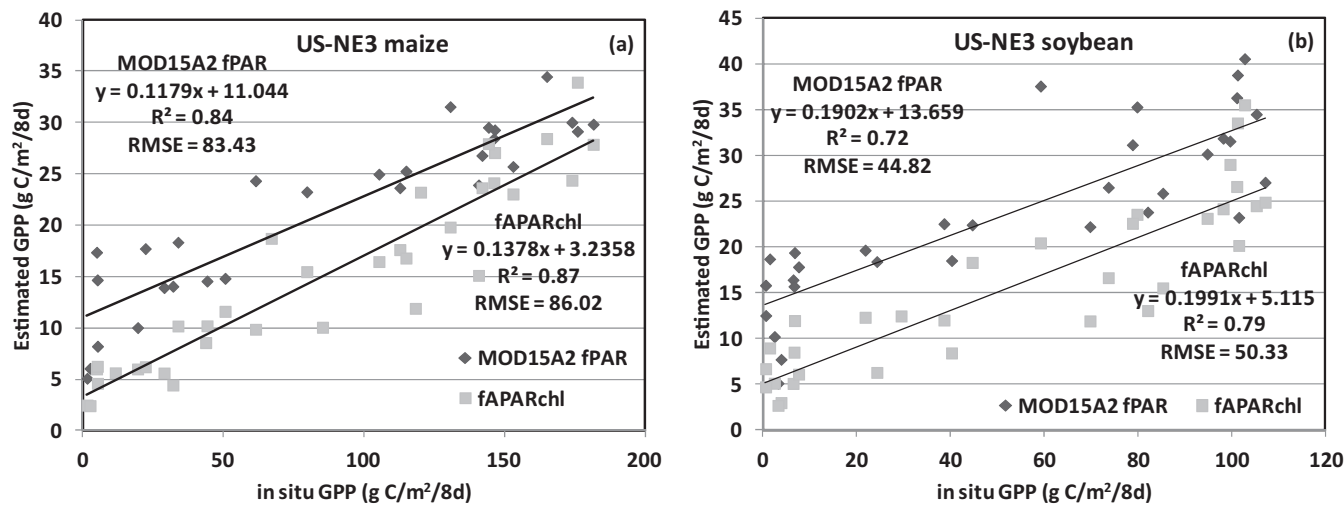

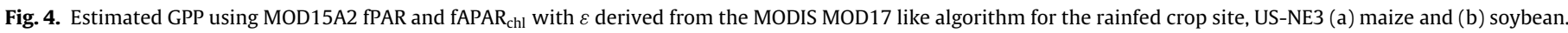

the two agricultural sites, US-NE2 and US-NE3, fAPAR chl $_{\text {exhibited }}$ seasonal patterns that were more similar to measured GPP than those obtained with MOD15A2 fPAR. However, the MOD15A2 fPAR described unrealistically longer growing seasons than those shown

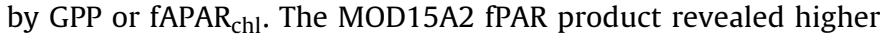
values in spring and fall, while GPP suggested low (or no) photosynthetic activities in the field. At the Bartlett forest site (US-BAR), GPP, and fAPAR $_{\text {chl }}$ showed a similar seasonal pattern and length of growing season (Fig. 2c), whereas the MOD15A2 fPAR product described these seasonal dynamics less accurately and exhibited much higher

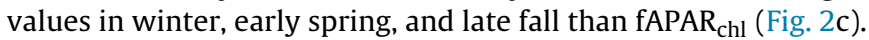

The GPP model (1) was applied using parameterization from the MODIS MOD17 product algorithm (Table 1 ) to determine LUE $(\varepsilon)$ coupled with either MOD15A2 fPAR (Table 2, Case I) or fAPAR chl (Case II) to model GPP for the three study sites. Comparisons between in situ GPP and estimated GPP for the US-NE2 site are shown in Fig 3. For both maize and soybean on the irrigated US-NE2 site, the estimates using fAPAR $\mathrm{chl}_{\mathrm{ch}}$ show consistently good linear relationships ( $\left.r^{2}=0.92-0.94\right)$ with flux tower based GPP (Fig. 3). Estimated GPP using MOD15A2 product showed less satisfactory $\left(r^{2}=0.61-0.78\right)$ results, with a noticeable offset for the regression line (Fig. 3). Nevertheless, clear GPP underestimations were observed with either APAR $_{\text {chl }}$ or MOD15A2 fPAR. Results for the rainfed US-NE3 site are summarized in Fig. 4, where GPP estimates obtained using either the MOD15A2 product or the APAR $_{\mathrm{chl}}$ were comparable ( $r^{2}=0.84-0.87$ for maize; $r^{2}=0.72-0.79$ for soybean). Stronger regressions were obtained for irrigated (Fig. 3) vs. rainfed (Fig. 4) fields using fAPAR $_{\text {chl }}$, but the opposite for the MOD15A2 product. Similar to the US-NE2 site, estimates using MOD15A2 product showed a more obvious offset, and clear underestimations were observed for both fPAR products (Figs. 3 and 4). For the Bartlett forest, estimates using fAPAR $\mathrm{Chl}_{\mathrm{s}}$ showed much stronger relationships to tower-based GPP $\left(r^{2}=0.91\right.$, Fig. 5) compared to the MOD15A2 product $\left(r^{2}=0.57\right)$. Nevertheless, estimates using the MOD15A2 product exhibited slightly lower RMSE that using fAPAR $_{\mathrm{chl}}$, and GPP estimates were closer to tower values than for fAPAR $_{\text {chl }}$ (Fig. 5).

In addition to using the $\varepsilon_{\max }$ values adapted from the MODIS MOD17 product algorithm (Table 1), we also applied an analytic approach based on NEE and PAR to determine the site specific value of $\varepsilon_{\max }$. For the US-NE2 sites, $0.004209 \mathrm{~kg} \mathrm{CMJ}^{-1}$ was retrieved for maize and $0.002606 \mathrm{~kg} \mathrm{CMJ}^{-1}$ was used for soybean.

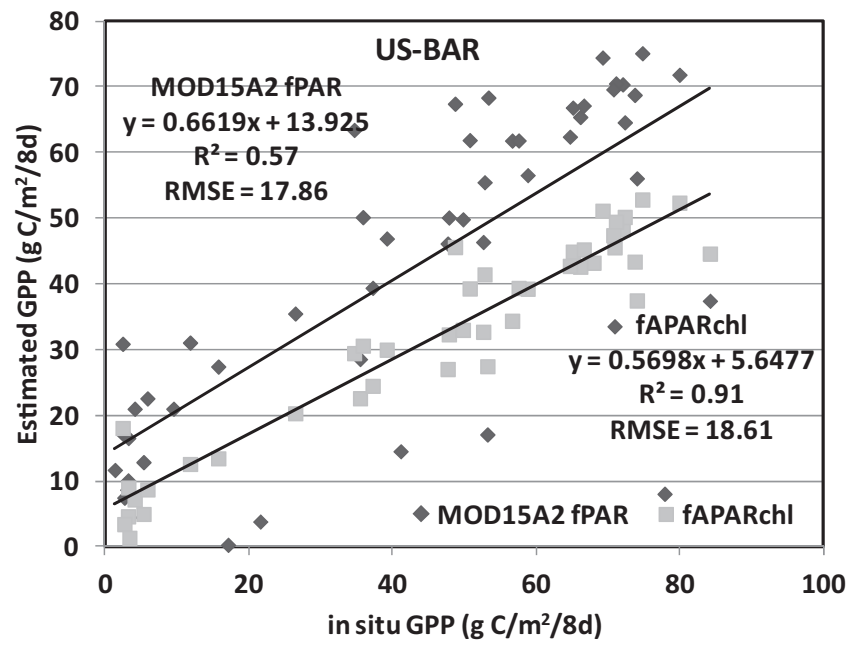

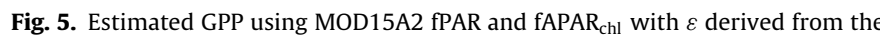
MODIS MOD17 like algorithm for the deciduous forest site, US-BAR. 

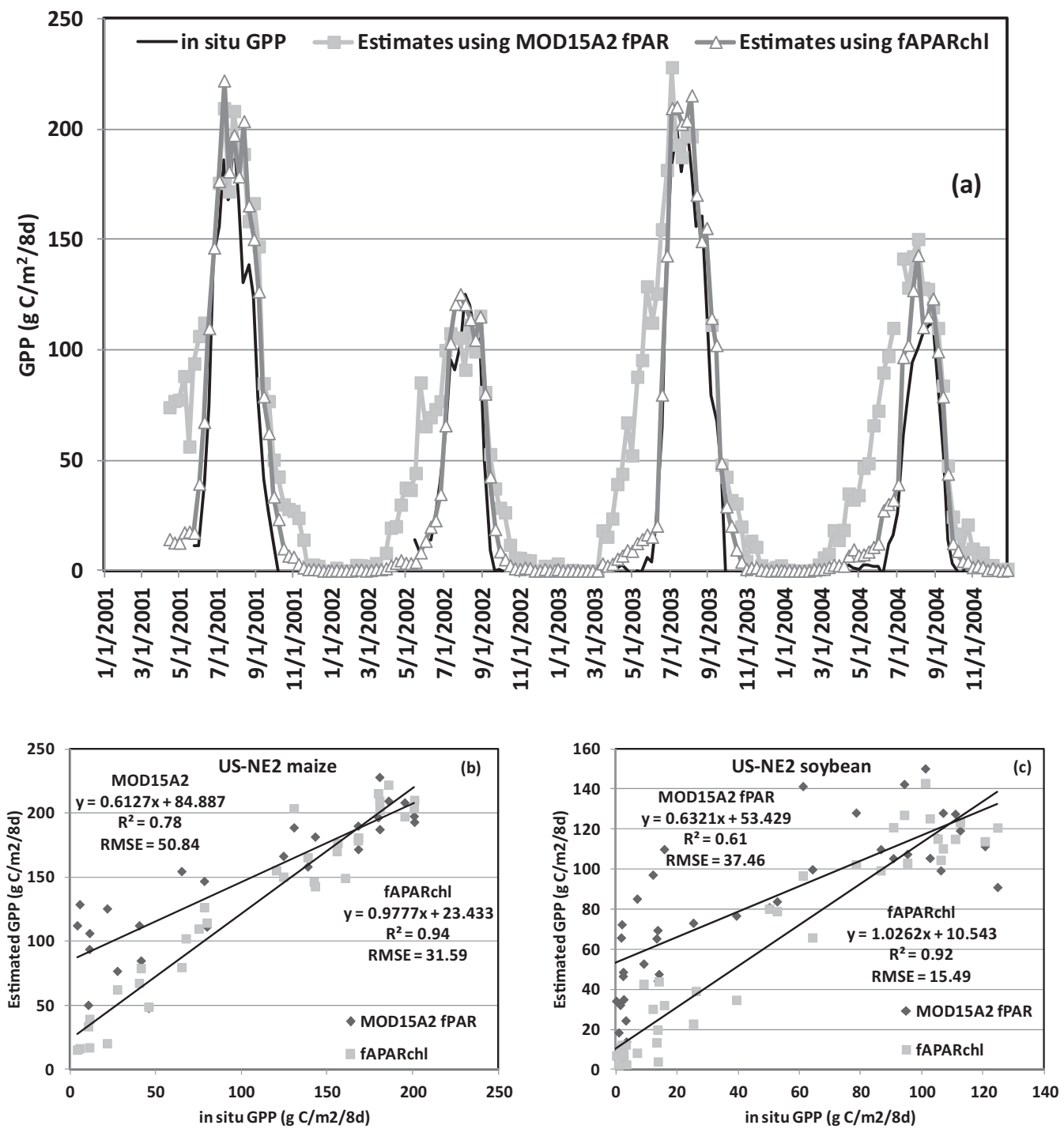

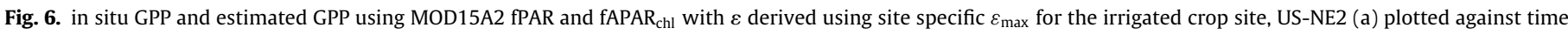
from 2001 through 2004, (b) comparisons for maize, (c) comparisons for soybean.

For the US-NE3 sites, $0.00555 \mathrm{~kg} \mathrm{CMJ}^{-1}$ was derived for maize and $0.002817 \mathrm{~kg} \mathrm{CMJ}^{-1}$ was used for soybean. For the US-BAR forest, $0.002006 \mathrm{~kg} \mathrm{C} \mathrm{MJ}^{-1}$ was used. These site specific $\varepsilon_{\max }$ values were used as input to the MODIS MOD17 product algorithm, Eq. (2), to derive $\varepsilon$. Flux tower based GPP and estimated GPP using the site specific $\varepsilon_{\text {max }}$ value coupled with MOD15A2 fPAR (Case III) and fAPAR chl $_{\text {f }}$ (Case IV) are plotted as a time series for the three study sites. Comparisons are shown as regression charts in Figs. 6-8. In general, improvements in the magnitude of GPP estimates and reductions in RMSE were observed, especially for the agricultural sites. Estimated

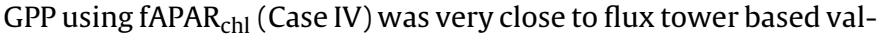
ues, for both maize and soybean (Figs. 6 and 7 a). For the Bartlett forest, a slight decrease in RMSE was observed for estimates using fAPAR $_{\text {chl }}$, but a clear increase in RMSE and GPP overestimates were observed for estimates using the MOD15A2 fPAR product paired with the site-specific $\varepsilon_{\max }$ (Fig. 8b).

\section{Discussion}

In this study, we utilized different approaches to derive two important parameters needed for carbon modeling, LUE $(\varepsilon)$ and fPAR, with a simple GPP model. Performance of these approaches was assessed for simulated GPP, as compared to in situ flux tower GPP.

All three study sites exhibited seasonal GPP patterns (Fig. 1), as expected. In both the maize-soybean rotation sites (US-NE2 and US-NE3), the C4 plant, maize, showed higher GPP values than the C3 plant, soybean. Furthermore, we noticed higher GPP values for irrigated crops (Fig. 1a) than rainfed crops (Fig. 1b) that could be attributed to water availability. For the agricultural sites, little or no green biomass should be expected outside of the growing season. After planting, clear patterns of growing season were observed from the early vegetative stage, the mature and reproductive stage, to the senescence stage. Seasonal dynamics of $\mathrm{fAPAR}_{\mathrm{chl}}$ closely matched GPP for both of the agricultural sites. The MOD15A2 fPAR product showed similar values to $\mathrm{AAPAR}_{\mathrm{chl}}$ during the peak of the growing season (approximately mid-July, Fig. 2a, b) but higher values for the rest of the year. The time series of MOD15A2 fPAR product also suggested earlier green-up and later senescence, i.e. a longer duration of the growing season, than determined from either

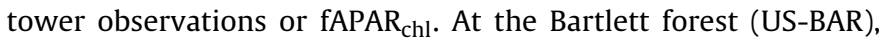
the MOD15A2 fPAR product had higher values than APAR $_{\text {chl }}$ not only outside growing season but also during the summer growing season (Fig. 2c). The duration of the growing season suggested by 

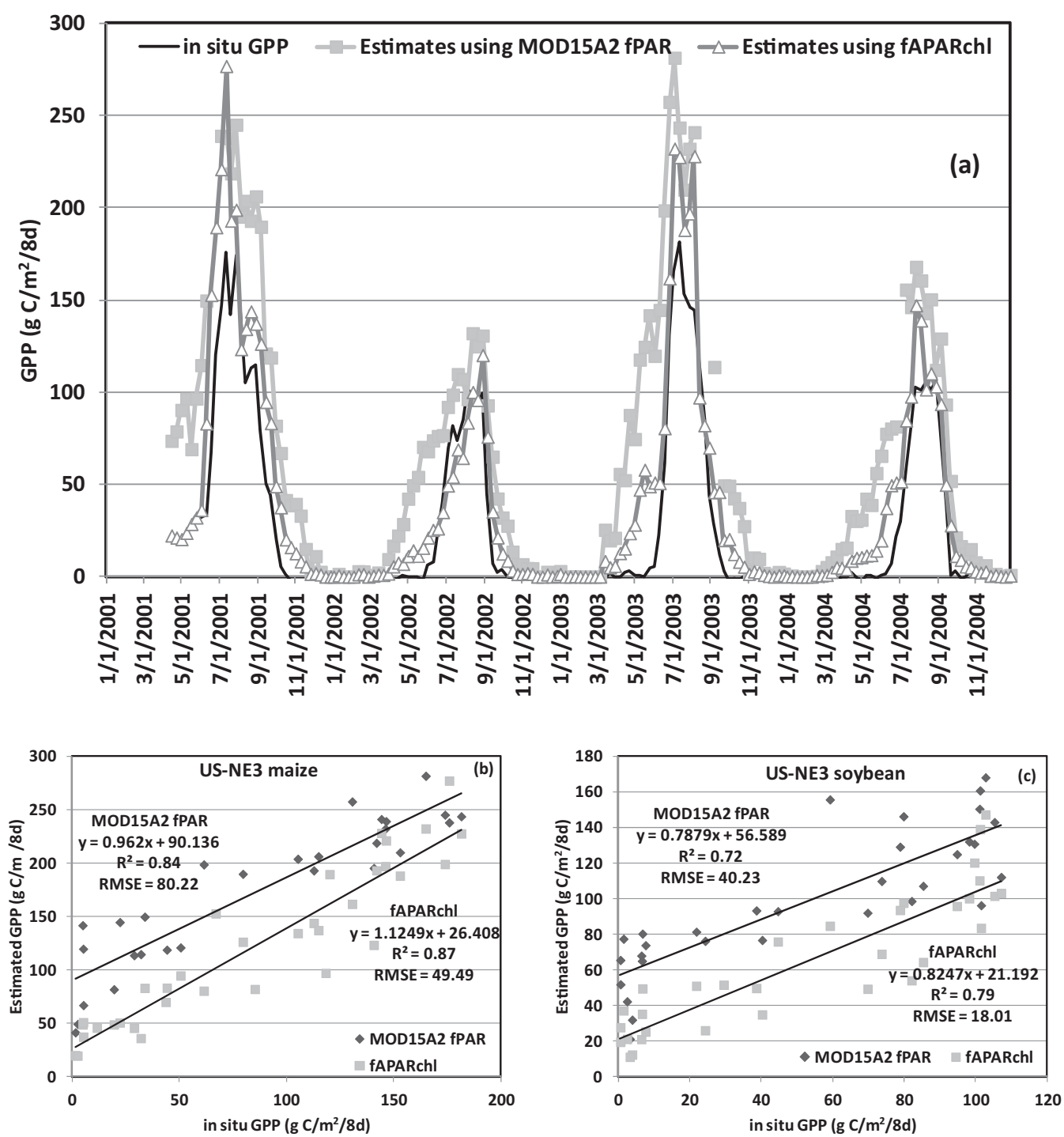

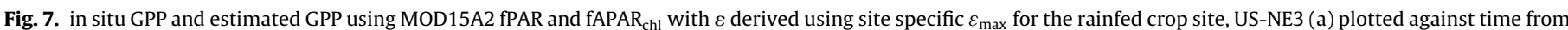
2001 through 2004, (b) comparisons for maize, (c) comparisons for soybean.

MOD15A2 fPAR at the US-BAR site also appeared longer compared with fAPAR $_{\mathrm{chl}}$ and GPP. MOD15A2 fPAR suggested a slightly earlier green-up and a later senescence (Fig. 1c).

For all the study sites little or no green biomass should be expected outside of the growing season. Flux tower based GPP also showed little or no photosynthetic activities between senescence and green-up. The fAPAR $_{\text {chl }}$ exhibited seasonal variations matching the expectation. The MODIS MOD15A2 fPAR product seemed to have an overestimation bias for all three sites during winter, early spring, and late fall. The fAPAR ${ }_{\mathrm{chl}}$ is a parameter proposed here to account for the fraction of PAR absorbed by chlorophyll in leaves, only which will be used in the photosynthesis process. Theoretically, this parameter minimizes the effects caused by the non-green component of leaf and canopy (e.g. non-photosynthetic pigment and stem) as well as soil background. This might explain the lower values of FAPAR $_{\mathrm{chl}}$ than MODIS fPAR product. This feature might also make fAPAR $_{\mathrm{chl}}$ a land surface parameter that is closer to the "true" physiological and phenological condition, both during and outside the growing season.

The results from coupled MODIS FPAR and APAR $_{\text {chl }}$ with the LUE $(\varepsilon)$ value derived from the algorithm similar to the MODIS MOD17 product are shown in Figs. 3-5. Estimates using fAPAR chl consistently produced better agreement with in situ GPP values for all the three study sites. This suggests that fAPAR chl $_{\text {might }}$ be used as an alternative option than the standard MOD15A2 fPAR product as input to carbon models to improve our current capabilities in carbon modeling and monitoring. As shown in the regression charts (Figs. 3-5), estimates using MOD15A2 fPAR had more significant offsets than AAPAR $_{\text {chl. }}$. This is most likely due to the higher values of MOD15A2 fPAR exhibited outside of the growing season. A general underestimation of modeled GPP was found for two agricultural sites (Figs. 3 and 4). This might suggest an underestimation of $\varepsilon$ values for the crops using the algorithm similar to the MODIS MOD17 product. Similar underestimation was also found for the US-BAR sites, but was not as pronounced (Fig. 5). The differences in performance among sites could also be attributed to differences in plant functional types (C3 and C4 crops, broadleaf trees). The model we utilized in this study took the ability to capture and the efficiency to use solar radiation into account in GPP estimates. Such plant physiological properties vary among different vegetation types, and might explain the different performance as we observed at the three sites. Similarly, a recent study using plant biochemical properties and environmental conditions to estimate GPP (Wu et al., 2011) also reported that model calibration and performance can depend on plant functional types. 

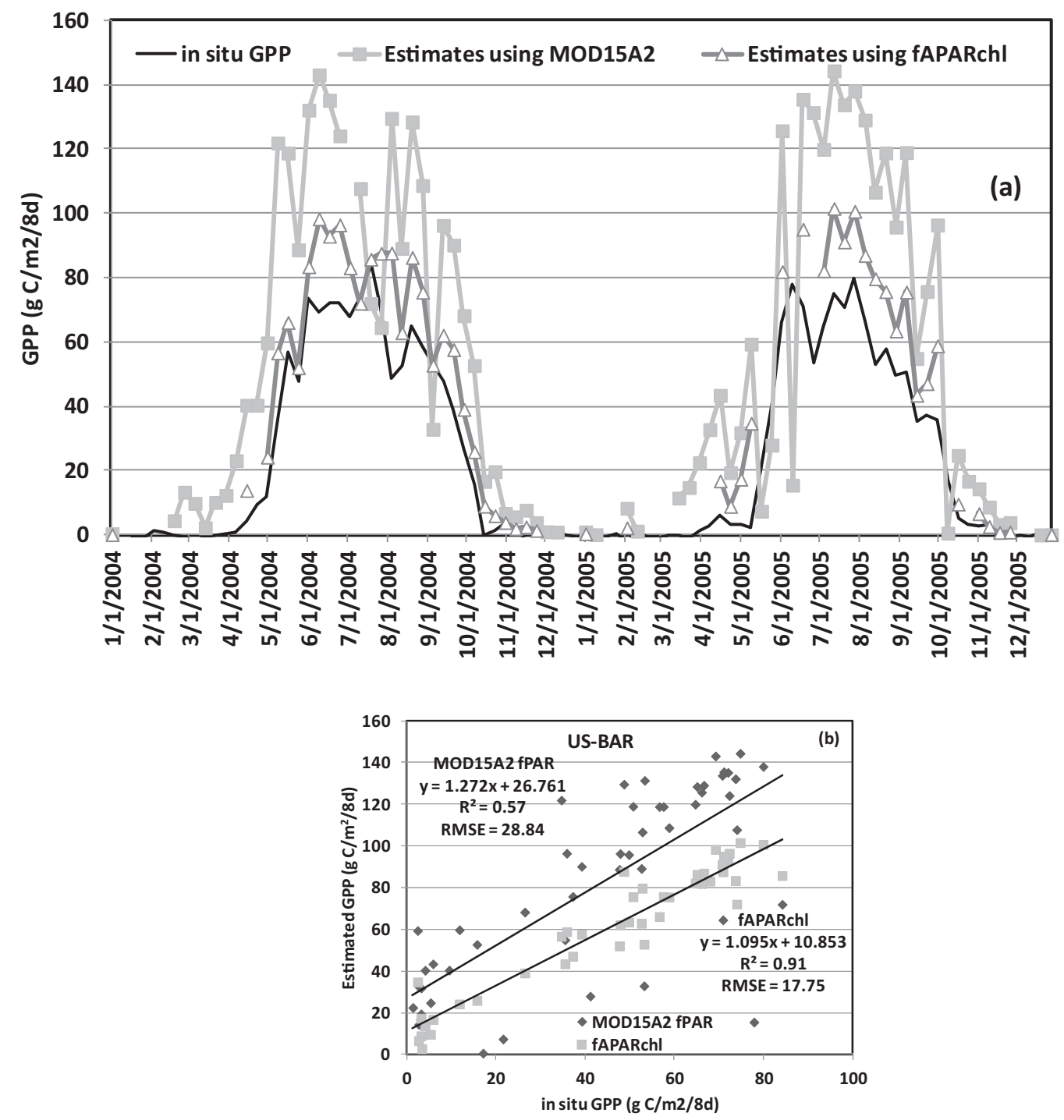

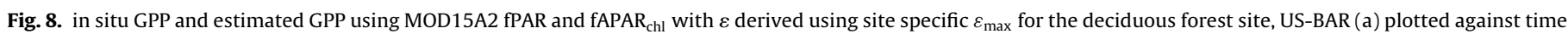
from 2004 and 2005, (b) comparison chart.

Using the site-specific $\varepsilon_{\max }$ values improved the accuracy of estimated GPP values, especially for the two agricultural sites (Figs. 6 and 7). As we discussed previously, the MOD15A2 fPAR produced GPP overestimation outside of the growing season in winter, early spring, and late fall for both the US-NE2 and US-NE3 sites. The

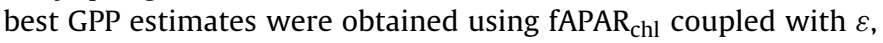
determined by the site specific $\varepsilon_{\text {max }}$ value and the MODIS MOD17 algorithm (Case IV). At the Bartlett forest, using site specific $\varepsilon_{\max }$

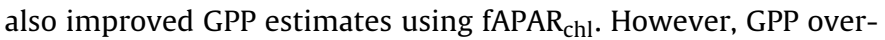
estimates resulted with the site-specific $\varepsilon_{\max }$ and with MOD15A2 fPAR. One may notice from the regression chart (Fig. 5), that GPP estimates using MOD15A2 fPAR paired with MOD17 LUE (Case I) were close to in situ GPP values when GPP values were high, most likely during peak of the growing season. This suggests that the simple model of using MOD15A2 fPAR and $\varepsilon$ values might have good performance for some study sites during the peak of the growing season. One should also note that the $\varepsilon_{\max }$ value can be obtained from literature review or derived using the analytical approach, which is affected by multiple parameters in the process including regression model type and the period of time of interests (Ruimy et al., 1995; Wang et al., 2010; Xiao et al., 2004a). Therefore, values vary among vegetation types, study sites, and duration times in different studies. Furthermore, recent studies have suggested the importance of taking both sunlit and shaded foliage into account for accurate LUE estimates (He et al., 2013; Middleton et al., 2009) since the shaded segment of the canopy is likely to experience less environmental stress (e.g., less solar radiation and lower temperature), and hence, has higher LUE. Therefore, an algorithm that integrates sunlit and shaded foliage might help to derive more accurate LUE values and improve GPP estimates (He et al., 2013).

\section{Summary}

We utilized a simple model with different LUE and PPAR estimates to simulate GPP for crops and a deciduous forest. Flux tower based GPP and APAR $_{\text {chl }}$ showed similar seasonal dynamics. The MODIS MOD15A2 fPAR showed higher values before green-up and after senescence, describing a longer duration of the growing season than actually occurred. Estimates using fAPAR chl $_{\text {consis- }}$ tently delivered better agreement with in situ GPP than MODIS fPAR. When utilizing $\varepsilon$ values derived using the MODIS MOD17like algorithm, underestimations of GPP were observed, especially at the agricultural sites. The best performance was found using site-specific $\varepsilon_{\text {max }}$ to derive LUE coupled with fAPAR chl $_{\text {. This study }}$ demonstrates the importance of accurate land surface parameterization to our current carbon monitoring capabilities. In the future, 
more study sites covering different vegetation types should be examined.

\section{Acknowledgements}

This study was supported by a NASA ROSES project, Grant No. NNX12AJ51G"Carbon Monitoring and Ecosystem Feedbacks Prediction Using fAPARch1 and the Community Land Model (CLM)" (PI, Q. Zhang), through the Terrestrial Ecology Program (Diane Wickland, manager). The work of A. Lyapustin and Y. Wang was supported by the NASA Earth Sciences Program. This work used eddy covariance data acquired by the FLUXNET community and in particular by the following networks: AmeriFlux (U.S. Department of Energy, Biological and Environmental Research, Terrestrial Carbon Program (DE-FG02-04ER63917 and DE-FG02-04ER63911), AfriFlux, AsiaFlux, CarboAfrica, CarboEuropeIP, Carboltaly, CarboMont, ChinaFlux, Fluxnet-Canada (supported by CFCAS, NSERC, BIOCAP, Environment Canada, and NRCan), GreenGrass, KoFlux, LBA, NECC, OzFlux, TCOS-Siberia, USCCC. We acknowledge the financial support to the eddy covariance data harmonization provided by CarboEuropeIP, FAO-GTOS-TCO, iLEAPS, Max Planck Institute for Biogeochemistry, National Science Foundation, University of Tuscia, Université Laval and Environment Canada and US Department of Energy and the database development and technical support from Berkeley Water Center, Lawrence Berkeley National Laboratory, Microsoft Research eScience, Oak Ridge National Laboratory, University of California - Berkeley, University of Virginia. The authors thank the anonymous reviewers for their very valuable suggestions and critiques.

\section{References}

Agarwal, D.A., Humphrey, M., Beekwilder, N.F., Jackson, K.R., Goode, M.M., van Ingen, C., 2010. A data-centered collaboration portal to support global carbon-flux analysis. Concurrency Computat. Pract. Exper. 22 (17), 2323-2334.

Anderson, M.C., Norman, J.M., Meyers, T.P., Diak, G.R., 2000. An analytical model for estimating canopy transpiration and carbon assimilation fluxes based on canopy light-use efficiency. Agric. Forest Meteorol. 101 (4), 265-289.

Baret, F., Fourty, T., 1997. Radiometric estimates of nitrogen status in leaves and canopies. In: Lemaire, G. (Ed.), Diagnosis of the Nitrogen Status in Crops. Springer, Berlin, pp. 201-227.

Beer, C., et al., Reichstein, M., Tomelleri, E., Ciais, P., Jung, M., Carvalhais, N., Rödenbeck, N., Arain, M.A., Baldocchi, D., Bonan, G.B., Bondeau, A., Cescatti, A., Lasslop, G., Lindroth, A., Lomas, M., Luyssaert, S., Margolis, H., Oleson, K.W., Roupsard, O., Veenendaal, E., Viovy, N., Williams, C., Woodward, F.I., Papale, D., 2010. Terrestrial gross carbon dioxide uptake: global distribution and covariation with climate. Science 329 (5993), 834-838.

Bonan, G.B., Lawerence, P.J., Oleson, K.W., Levis, S., Jung, M., Reichstein, M., Lawerence, D.M., Swenson, S.C., 2011. Improving canopy processes in the community land model version 4 (CLM4) using global flux fields empirically inferred from FLUXNET data. J. Geophys. Res. 116 (G2), G02014.

Braswell, B.H., et al., Schimel, D.S., Privette, J.L., Moore, B., Emery, W.J., Sulzman, E.W., Hudak, A.T., 1996. Extracting ecological and biophysical information from AVHRR optical data: an integrated algorithm based on inverse modeling. J. Geophys. Res. 101 (D18), 23335-23348.

Cheng, Y.-B., Middleton, E.M., Hilker, T., Coops, N.C., Black, T.A., Krishnan, P., 2009. Dynamics of spectral bio-indicators and their correlations with light use efficiency using directional observations at a Douglas-fir forest. Measure. Sci. Technol. 20 (9), 095107.

Cheng, Y.-B., Zarco-Tejada, P.J., Falk, M., Kyaw Tha Paw, U., Wharton, S., Ustin, S.L., 2007. Relationships between moderate resolution imaging spectroradiometer water indexes and tower flux data in an old growth conifer forest. J. Appl. Rem. Sens. 1 (23(May)), 013513.

Drolet, G.G., Middleton, E.M., Huemmrich, K.F., Hall, F.G., Amiro, B.D., Barr, A.G., Margolis, H.A., 2008. Regional mapping of gross light-use efficiency using MODIS spectral indices. Rem. Sens.Environ. 112 (6), 3064-3078.

Falge, E., Baldocchi, D., Olson, R., Anthoni, P., Aubinet, M., Bernhofer, C., Burba, G., Ceulemans, R., Clement, R., Dolman, H., Grainer, A., Grunwald, T., Hollinger, D., Jensen, N.-O., Katul, G., Keronen, P., Kowalski, A., Ta Lai, C., Law, B.E., Meyers, T., Moncrieff, J., Moors, E., Munger, J.W., Pilegaard, K., Rannik, U., Rebmann, C., Suyker, A.E., Tenhunen, J., Tu, K., Verma, S., Vesala, T., Wilson, K., Wofsy, S., 2001. Gap filling strategies for defensible annual sums of net ecosystem exchange. Ag. For. Meteorol. 107 (1), 43-69.

Gower, S.T., Kucharik, C.J., Norman, J.M., 1999. Direct and indirect estimation of leaf area index, fAPAR, and net primary production of terrestrial ecosystems. Rem. Sens. Environ. 70 (1), 29-51.
Grace, J., et al., Nichol, C., Disney, M., Lewis, P., Quaife, T., Bowyer, P., 2007. Can we measure terrestrial photosynthesis from space directly, using spectral reflectance and fluorescence? Global Change Biol. 13 (7), 1484-1497.

Hall, F.G., Hilker, T., Coops, N.C., 2012. Data assimilation of photosynthetic light-use efficiency using multi-angular satellite data: I. Model formulation. Rem. Sens. Environ. 121 (0), 301-308.

He, M., Ju, W., Zhou, Y., Chen, J., He, H., Wang, S., Wang, H., Guan, D., Yan, J., Li, Y., Hao, Y., Zhao, F., 2013. Development of a two-leaf light use efficiency model for improving the calculation of terrestrial gross primary productivity. Agric. Forest Meteorol. 173 (0), 28-39.

Heinsch, F.A., Heinsch, F.A., Reeves, M., Votava, P., Kang, S., Milesi, C., Zhao, M., Running, S.W., 2003. User's Guide, GPP and NPP (MOD17A2/A3) Products, NASA MODIS Land Algorithm. University of Motana, Missoula, MT.

Heinsch, F.A., Zhao, M., Running, S.W., Kimball, J.S., Nemani, R.R., Davis, K.J., Bolstad, P.V., Cook, B.D., Desai, A.R., Ricciuto, D.M., Law, B.E., Oechel, W.C., Kwon, H., Luo, H., Wofsy, S.C., Allison, L.D., Munger, J.W., Baldocchi, D.D., Xu, L., Hollinger D.Y., Richardson, A.D., Stoy, P.C., Siqueira, M.B.S., Monson, R.K., Burns, S.P., Flanagan, L.B., 2006. Evaluation of remote sensing based terrestrial productivity from MODIS using regional tower eddy flux network observations. IEEE Trans. Geosci. Rem. Sens. 44 (7), 1908-1925.

Hilker, T., et al., Hall, F.G., Tucker, C.J., Coops, N.C., Black, T.A., Nichol, C.J., Sellers, P.J., Barr, A., Hollinger, D.Y., Munger, J.W., 2012. Data assimilation of photosynthetic light-use efficiency using multi-angular satellite data: II Model implementation and validation. Rem. Sens. Environ. 121 (0), 287-300.

Houborg, R., Anderson, M.C., Daughtry, C.S.T., Kustas, W.P., Rodell, M., 2011. Using leaf chlorophyll to parameterize light-use-efficiency within a thermal-based carbon, water and energy exchange model. Rem. Sensing Environ. 115 (7), 1694-1705.

Huete, A.R., Didan, K., Miura, T., Rodriguez, E.P., Gao, X., Ferreira, L.G., 2002. Overview of the radiometric and biophysical performance of the MODIS vegetation indices. Rem. Sensing Environ. 83 (1-2), 195-213.

Huntzinger, D.N., Post, W.M., Wei, Y., Michalak, A.M., West, T.O., Jacobson, A.R., Baker, I.T., Chen, J.M., Davis, K.J., Hayes, D.J., Hoffman, F.M., Jain, A.K., Liu, S., McGuire A.D., Neilson, R.P., Potter, C., Poulter, B., Price, D., Raczka, B.M., Tian, H.Q., Thornton, P., Tomelleri, E., Viovy, N., Xiao, J., Yuan W., Zeng, N., Zhao, M., Cook, R., 2012. North American carbon program (NACP) regional interim synthesis: terrestrial biospheric model intercomparison. Ecol. Model. 232 (0), 144-157.

Jacquemoud, S., Baret, F., 1990. PROSPECT: a model of leaf optical properties spectra. Rem. Sensing Environ. 34 (2), 75-91.

Jenkins, J.P., Jenkins, J.P., Richardson, A.D., Braswell, B.H., Ollinger, S.V., Hollinger D.Y., Smith, M.L., 2007. Refining light-use efficiency calculations for a deciduous forest canopy using simultaneous tower-based carbon flux and radiometric measurements. Ag. For. Meteorol. 143 (1-2), 64-79.

Jin, C., Jin, C., Xiao, X., Merbold, L., Arneth, A., Veenendaal, E., Kutsch, W.L., 2013. Phenology and gross primary production of two dominant savanna woodland ecosystems in Southern Africa. Rem. Sens. Environ. 135 (0), 189-201.

Kalfas, J.L., Xiao, X., Vanegas, D.X., Verma, S.B., Suyker, A.E., 2011. Modeling gross primary production of irrigated and rain-fed maize using MODIS imagery and CO2 flux tower data. Agric. Forest Meteorol. 151 (12), 1514-1528.

Knyazikhin, Y.,. Glassy, J., Privette, JL, Tian, Y., Lotsch, A. and Zhang, Y., 1999. MODIS Leaf Area Index (LAI) And Fraction Of Photosynthetically Active Radiation Absorbed By Vegetation (FPAR) Product (MOD15) Algorithm Theoretical Basis Document.

Knyazikhin, Y., Martonchik, J.V., Myneni, R.B., Diner, D.J., Running, S.W., 1998. Synergistic algorithm for estimating vegetation canopy leaf area index and fraction of absorbed photosynthetically active radiation from MODIS and MISR data. J.Geophys. Res. Atmosph. 103 (D24), 32257-32275.

Lin, J.C., Pejam, M.R., Chan, E., Wofsy, S.C., Gottlieb, E.W., Margolis, H.A., McCaughey, J.H., 2011. Attributing uncertainties in simulated biospheric carbon fluxes to different error sources. Global Biogeochem. Cycle. 25 (2), GB2018.

Lyapustin, A., Martonchik, J., Wang, Y., Laszlo, I., Korkin, S., 2011a. Multiangle implementation of atmospheric correction (MAIAC): 1. Radiative transfer basis and look-up tables. J. Geophys. Res. Atmosph. 116 (D3), D03210.

Lyapustin, A., Wang, Y., Laszlo, I., Kahn, R., Korkin, S., Remer, L., Levy, R., Reid, J.S., 2011b. Multiangle implementation of atmospheric correction (MAIAC): 2. Aerosol algorithm. J. Geophys. Res. Atmosph. 116 (D3), D03211.

Lyapustin, A.I., Wang, Y., Laszlo, I., Hilker, T., Hall, F.G., Sellers, P.J., Tucker, C.J., Korkin, S.V., 2012. Multi-angle implementation of atmospheric correction for MODIS (MAIAC): 3. Atmospheric correction. Rem. Sens. Environ. 127 (0), 385-393.

Middleton, E.M., Cheng, Y.-B., Hilker, T., Black, T.A., Krishnan, P., Coops, N.C., Huemmrich, K.F., 2009. Linking foliage spectral responses to canopy level ecosystem photosynthetic light use efficiency at a Douglas-fir forest in Canada. Can. J. Rem. Sens. 35 (2), 166-188

Middleton, E.M., Huemmrich, K.F, Cheng Y.B, Margolis, H.A, 2011. Spectral bioindicators of photosynthetic efficiency and vegetation stress. In: Thenkabail P.S., Lyon, J.G., Huete, A. (Eds.), Hyperspectral Remote Sensing of Vegetation. CRC Press, pp. 265-288.

Monteith, J.L., 1972. Solar-radiation and productivity in tropical ecosystems. J. Appl. Ecol. 9 (3), 747-766

Monteith, J.L., 1977. Climate and the efficiency of crop production in Britain. Phil. Trans. R. Soc. B 281 (980), 277-294.

Munger, J., Loescher, H., 2006. Guidelines for Making Eddy Covariance Flux measurements. Ameriflux.

Myneni, R.B., et al., Hoffman, S., Knyazikhin, Y., Privette, J.L., Glassy, J., Tian, Y., Wang, Y., Song, X., Zhang, Y., Smith, G.R., Lotsch, A., Friedl, M., Morisette, J.T., Votava, P., Nemani, R.R., Running, S.W., 2002. Global products of vegetation leaf area 
and fraction absorbed PAR from year one of MODIS data. Rem. Sens. Environ. 83 (1-2), 214-231.

Nichol, C.J., Huemmrich, K.F., Black, T.A., Jarvis, P.G., Walthall, C.L., Grace, J., Hall, F.G., 2000. Remote sensing of photosynthetic-light-use efficiency of boreal forest. Agric. Forest Meteorol. 101 (2-3), 131-142.

Peng, Y., Gitelson, A.A., 2012. Remote estimation of gross primary productivity in soybean and maize based on total crop chlorophyll content. Rem. Sens. Environ. 117 (0), 440-448.

Ruimy, A., Jarvis, P.G., Baldocchi, D.D., Saugier, B., 1995. CO2 Fluxes over plant canopies and solar radiation: a review. In: Begon, M., Fitter, A.H. (Eds.), Advances in Ecological Research. Academic Press, pp. 1-68.

Running, S.W., Nemani, R.R., Heinsch, F.A., Zhao, M., Reeves, M., Hashimoto, H., 2004. A continuous satellite-derived measure of global yerrestrial primary production. BioScience 54 (6), 547-560.

Schaefer, K., Schwalm, C.R., Williams, C., Arain, M.A., Barr, A., Chen, J.M., Davis, K.J., Dimitrov, D., Hilton, T.W., Hollinger, D.Y., Humphreys, E., Poulter, B., Raczka, B.M., Richardson, A.D., Sahoo, A., Thornton, P., Vargas, R., Verbeeck, H., Anderson, R., Baker, I., Black, T.A., Bolstad vP., Chen, J., Curtis, P.S., Desai, A.R., Dietze, M., Dragoni, D., Gough, C., Grant, R.F., Gu, L., Jain, A., Kucharik, C., Law, B., Liu, S., Lokipitiya, E., Margolis, H.A., Matamala, R., McCaughey, J.H., Monson, R., Munger, J.W., Oechel, W., Peng, C., Price, D.T., Ricciuto, D., Riley, W.J., Roulet, N., Tian, H., Tonitto, C., Torn, M., Weng, E., Zhou, X., 2012. A model-data comparison of gross primary productivity: results from the North American carbon program site synthesis. J. Geophys. Res. Biogeosci. 117 (G3), G03010.

Sellers, P.J., Sellers, P.J., Dickinson, R.E., Randall, D.A., Betts, A.K., Hall, F.G., Berry, J.A., Henderson-Sellers, A., 1997. Modeling the exchange of energy, water, and carbon between continents and the atmosphere. Science 275, 502-509.

Tucker, C.J., Sellers, P.J., 1986. Satellite remote sensing of primary production. Int. J. Rem. Sens. 7 (11), 1395-1416.

Turner, D.P., et al., Turner, D.P., Ritts, W.D., Cohen, W.B., Gower, S.T., Running, S.W., Zhao, M., Ahl, D.E., 2006. Evaluation of MODIS NPP and GPP products across multiple biomes. Rem. Sens. Environ. 102 (3-4), 282-292.

Verma, S.B., et al., Dobermann, A., Cassman, K., Walters, D.T., Knops, J.M., Arkebauer, T.J., Suyker, A.E., Burba, G.G., Amos, B., Yang, H.S., Ginting, D., Hubbard, K.G., Gitelson, A.A., Walter-Shea, E.A., 2005. Annual carbon dioxide exchange in irrigated and rainfed maize-based agroecosystems. Ag. For. Meteorol. 131 (1-2), 77-96.

Wang, Z., Xiao, X., Yan, X., 2010. Modeling gross primary production of maize cropland and degraded grassland in northeastern China. Agric. Forest Meteorol. 150 (9), 1160-1167.

Wofsy, S.C., Goulden, M.L., Munger, J.W., Fan, S.-M., Bakwin, P.S., Daube, B.C., Bassow, S.L., Bazzaz, A., 1993. Net exchange of $\mathrm{CO}_{2}$ in a mid-latitude forest. Science 260 (5112), 1314-1317.

Wu, C., Chen, J.M., Huang, N., 2011. Predicting gross primary production from the enhanced vegetation index and photosynthetically active radiation: evaluation and calibration. Rem. Sens. Environ. 115 (12), 3424-3435.
Wu, C., Niu, Z., Tang, O., Huang, W., Rivard, B., Feng, J., 2009. Remote estimation of gross primary production in wheat using chlorophyll-related vegetation indices. Agric. Forest Meteorol. 149 (6-7), 1015-1021.

Xiao, X., 2006. Light absorption by leaf chlorophyll and maximum light use efficiency. IEEE Trans. Geosci. Rem. Sens. 44 (7), 1933-1935.

Xiao, X., Hollinger, D., Aber, J., Goltz, M., Davidson, E.A., Zhang, Q., Moore III, B., 2004a. Satellite-based modeling of gross primary production in an evergreen needleleaf forest. Rem. Sens. Environ. 89 (4), 519-534.

Xiao, X., Zhang, Q., Braswell, B., Urbanski, S., Boles, S., Wofsy, S., Ojima, D., 2004b. Modeling gross primary production of temperate deciduous broadleaf forest using satellite images and climate data. Rem. Sens. Environ. 91 (2), 256-270.

Xiao, X., Zhang, Q., Saleska, S., Hutyra, L., De Camargo, P., Wofsy, S., Moore III, B., 2005. Satellite-based modeling of gross primary production in a seasonally moist tropical evergreen forest. Rem. Sens. Environ. 94 (1), 105-122.

Xiao, J., Zhuang, Q., Law, B.E., Chen, J., Baldocchi, D.D., Cook, D.R., Wofsy, S.C., 2010. A continuous measure of gross primary production for the conterminous United States derived from MODIS and AmeriFlux data. Rem. Sens. Environ. 114 (3), 576-591.

Zhang, Q., Middleton, E.M., 2010. Introduction to fraction of absorbed PAR by canopy chlorophyll (fAPARchl) and canopy leaf water content derived from Hyperion, simulated HyspIRI and MODIS images. In: IEEE International Geoscience \& Remote Sensing Symposium (IGARSS), Honolulu, HI.

Zhang, Q., Xiao, X., Braswell, B., Linder, E., Baret, F., Moore III, B., 2005. Estimating light absorption by chlorophyll, leaf and canopy in a deciduous broadleaf forest using MODIS data and a radiative transfer model. Rem. Sens. Environ. 99 (3), 357-371.

Zhang, Q., Xiao, X., Braswell, B., Linder, E., Ollinger, S., Smith, M.L., Minocha, R., 2006. Characterization of seasonal variation of forest canopy in a temperate deciduous broadleaf forest, using daily MODIS data. Rem. Sens. Environ. 105 (3), 189-203.

Zhang, Q., Middleton, E.M., Margolis, H.A., Drolet, G.G., Barr, A.A., Black, T.A., 2009. Can a satellite-derived estimate of the fraction of PAR absorbed by chlorophyll (FAPARchl) improve predictions of light-use efficiency and ecosystem photosynthesis for a boreal aspen forest? Rem. Sens. Environ. 113 (4), 880-888.

Zhang, Q., Middleton, E.M., Gao, B.C., Cheng, Y.-B., 2012. Using EO-1 Hyperion to simulate HyspIRI products for a coniferous Forest: the fraction of PAR absorbed by chlorophyll ( FAPAR $_{\text {chl }}$ ) and leaf water content (LWC). IEEE Trans. Geosci. Rem. Sens. 50 (5), 1844-1852.

Zhang, Q., Middleton, E.M., Cheng, Y.-B., Landis, D.R., 2013. Variations of foliage chlorophyll fAPAR and foliage non-chlorophyll fAPAR (fAPARchl, fAPARnon-chl) at the Harvard Forest,. IEEE J. Selected Topics Appl. Earth Observ. Rem. Sens., In press.

Zhao, M., Heinsch, F.A., Nemani, R.R., Running, S.W., 2005. Improvements of the MODIS terrestrial gross and net primary production global data set. Rem. Sens. Environ. 95 (2), 164-176. 